\title{
Comparing volcanic glass shards in unfertilized and fertilized Andisols derived from rhyolitic tephras, New Zealand: evidence for accelerated weathering and implications for land management
}

\section{Matthew D. Taylor ${ }^{1}$, David J. Lowe ${ }^{2}$, Peter Hardi ${ }^{3}$, Geerd A. Smidt ${ }^{4}$ and Ewald Schnug ${ }^{3}$}

${ }^{1}$ Waikato Regional Council, P.O. Box 4010, Hamilton East, Hamilton, New Zealand 3247

${ }^{2}$ School of Science, The University of Waikato, Private Bag 3105, Hamilton, New Zealand 3240

${ }^{3}$ Institute of Crop and Soil Science, Federal Research Centre for Cultivated Plants - Julius

Kuehn-Institut, D-38116 Braunschweig, Germany

${ }^{4}$ Jacobs University, School of Engineering \& Science - SES, Earth and Space Sciences, Campus Ring 1, D-28759 Bremen, Germany

*Corresponding author. Phone +6478590999. Email:matthew.taylor@waikatoregion.govt.nz

Final manuscript version (Feb 2016). See Geoderma for definitive version.

Citation:

Taylor, M.D., Lowe, D.J., Hardi, P., Smidt, G., Schnug, E. 2016. Comparing volcanic glass shards in unfertilised and fertilised Andisols derived from rhyolitic tephras, New Zealand: evidence for accelerated weathering and implications for land management. Geoderma 271, 91-98.

http://dx.doi.org/10.1016/j.geoderma.2016.01.035 


\section{Highlights}

- We examined glass shards from two Andisols of different age and fertilizer history

- The average sizes and angularities of the glass shards decreased with soil age

- The shard size and angularity decreases were more marked in the fertilized soils

- Additions of phosphatic, F-containing fertilizer had enhanced the glass dissolution

\section{Keywords}

Dealumination, clay minerals, allophane, fluoride, Udands, Vitrands 


\section{Abstract}

Enhanced weathering associated with the use of phosphate fertilizers has been identified in some of the major farming areas of New Zealand and an evaluation of its effects on soil properties and the implications for soil management are needed. We assessed changes in the character of volcanic glass shards in topsoils $(0-10 \mathrm{~cm}$ depth) of two tephra-derived Andisols of differing ages (Udivitrands, Hapludands), and with and without long-term fertilization, to test if fertilizing accelerates the weathering of soil constituents. Using visual assessment based on scanning electron microscopy and electron microprobe analyses of glass shards from samples from paired sites, we showed that the average sizes of the shards and the sharpness of the glass-shard edges (angularity) diminished with the age of the soil, and that these decreases were more marked in the soils that had been fertilized. Silica polymorphs were observed only in the older soil (Hapludand) that had been fertilized. We concluded that the addition of phosphate-containing fertilizer enhanced the dissolution of volcanic glass, consistent with phosphoric acid and $\mathrm{F}^{-}$-induced dealumination and desilication, and thus soil weathering has been accelerated. The $\mathrm{Al}$ and $\mathrm{Si}$ may subsequently coprecipitate as secondary minerals, such as allophane. However, silica polymorphs may form where Al activity is low. The occurrence of neogenic silica in topsoils (despite high annual rainfall that should result in desilication of the topsoil and reprecipitation of silica deeper in the soil) is explained by the seasonality of fertilizer application and the spring-summer climate, where the soil remains moist for periods sufficiently long enough for the dissolution of volcanic glass (and possibly of other aluminosilicates), the formation of Al-humus complexes, and the subsequent precipitation of silica in dry periods. Implications of the accelerated weathering for soil and land management are discussed. 


\section{Introduction}

Dealumination of clay minerals is a phenomena not often described in soils. Jackson et al. (1952) proposed that the reduction in charge of dioctahedral micas may occur from dealumination, being, in this case, substitution of $\mathrm{Si}$ for $\mathrm{Al}$ in the tetrahedral layer, while Gjems (1970) reported dealumination during the pedogenic weathering of clays in a podzol when the pH dropped below 4.5. More recently, Egli et al. (2004) reported F- and humusmediated dealumination of 2:1 clay minerals and consequent formation of smectites.

In New Zealand, dealumination has also been described in some volcanic-ash (tephra) derived soils. Taylor et al. (2012) and Taylor and Kim (2009) presented evidence for the dealumination of soil minerals by accelerated weathering or chemical attack on aluminosilicates. Increased concentrations of acid-extractable Al were observed in soils obtained from the Bay of Plenty, Auckland, and Waikato regions of northern North Island, New Zealand, for farmed land that had receive substantial inputs of phosphate fertilizers since about 1950, but not for unfertilized forested land. Two specific mechanisms were proposed: (1) partial dissolution of clay minerals by local areas of temporal high acidity associated with phosphate fertilizer granules; and (2) surface complexation and extraction by the fluoride and residual hydrofluoric acid present in phosphate fertilizers (superphosphate may contain up to 2\% F: Cronin et al., 2000; Mirlean and Roisenberg, 2007).

The likelihood that nitrogen fertilisers had a role in accelerated weathering was discussed in Taylor and Kim (2009) and rejected. Briefly, soil acidification because of nitrification of urea may be caused by $\mathrm{N}$ inputs greater than those assimilated by biota and stored either in biota or soil organic matter, the imbalance of cation over anion uptake by plants, loss of $\mathrm{NO}_{3}-\mathrm{N}$ due to leaching, and incomplete return to soil of the alkalinity of organic anions removed in products (Bolan et al., 1991; Barak et al., 1997). Soil acidification 
is also partly neutralised by $\mathrm{OH}^{-}$released when $\mathrm{NO}_{3}{ }^{-}$is taken up and assimilated by biota (Bouman et al., 1995). Thus, the net reaction of nitrogen addition, nitrification, and uptake by biota is acid/base neutral (Barak et al., 1997). Hence, although Bouman et al. (1995) recorded $\mathrm{pH}$ values as low as 4.3 , the solubility of $\mathrm{Al}$ did not increase substantially as $\mathrm{pH}$ decreased. In addition, soil acidification is managed by application of lime in New Zealand farm systems. Monitoring of New Zealand soils shows that farm management, generally, ensures soil pH levels are meeting the optimum required by the plants grown under the different land uses in New Zealand, and pH rarely drops below 5.5 (e.g. Taylor, 2015). A variety of hydroxyl groups are found on the surface of the soil matrix as $\mathrm{OH}^{-}$replacement of $\mathrm{O}^{2-}$ on the surface of $\mathrm{Al}, \mathrm{Fe}, \mathrm{Si}$, and $\mathrm{Mn}$ oxides in clay minerals results in reactive $\mathrm{OH}^{-}$on the mineral surfaces. The reactive $\mathrm{OH}^{-}$may be released from the mineral surface by complexation with oxianions. So, as $\mathrm{H}_{2} \mathrm{PO}_{4}{ }^{-}$ions are adsorbed onto the surface functional groups of soil colloids, i.e. by ligand exchange, part of the soil acidity produced is neutralised (Parfitt, 1978; Goldberg and Sposito, 1985).

Exposure of aluminosilicates to the two specific mechanisms proposed above results in dealumination, namely the extraction of $\mathrm{Al}$, and presumably $\mathrm{Si}$, from the mineral or mineraloid matrix. The process of dealumination is important because the breakdown of primary minerals and volcanic glass results in elements that were normally retained inside the residual phases of aluminosilicates becoming more mobile and potentially bioavailable (Taylor and Kim, 2009). Such elements include the environmentally sensitive trace elements $\mathrm{Ag}, \mathrm{Bi}, \mathrm{Sn}, \mathrm{Tl}$, and U.

Much of the central North Island has been blanketed with deposits of silica-rich rhyolitic tephras derived from eruptions of the Taupo, Okataina, and Tuhua volcanic centres (Lowe and Palmer, 2005), which weather mainly to allophane or halloysite, or both, 
depending on a range of factors, forming mainly Andisols (Ugolini and Dahlgren, 1991; Dahlgren et al., 2004; Hiradate and Wada, 2005; McDaniel et al., 2012). Andesitic tephras have also been deposited but these are much less voluminous and thinner than the rhyolitic tephras by several orders of magnitude. Rhyolitic tephras typically contain abundant fragments (pyroclasts) of Si-rich glass and glassy vesicular pumice clasts relatively low in $\mathrm{Al}$ (compared with basaltic glass). Such fragmental, glassy materials in soils can weather through hydrolysis even more readily than accompanying crystals or lithics because of the high surface area, vesicularity, and thermodynamic instability of glass (Churchman and Lowe, 2012), thereby releasing Si, Al, and other elements for mineral neogenesis (Hiradate and Wada, 2005).

Volcanic glasses dissolve through sequential removal of metals from the glass structure via proton exchange reactions (Hiradate and Wada, 2005; Gislason and Oelkers, 2003; Declercq et al., 2013). The overall dissolution rate is controlled by the detachment of Si tetrahedral that have been partially liberated from the glass structure through the removal of adjoining $\mathrm{Al}$ and the concomitant transformation of $\mathrm{Al}$ from its tetrahedral to octahedral state (Hiradate and Wada, 2005). Strongly adsorbing anions such as $\mathrm{PO}_{4}{ }^{2-}$ and $\mathrm{F}^{-}$can act in the same way as $\mathrm{OH}^{-}$and increase glass dissolution rate, even in acidic conditions. The potential role of $\mathrm{F}^{-}$is discussed further below. If F-containing phosphate fertilizer additions are accelerating the weathering of soil constituents then such changes should be observable by examining changes in the character of volcanic glass. In our study, we evaluated the effect of long-term fertilizer additions on the character of volcanic glass fragments in topsoils ( 0 to $10 \mathrm{~cm}$ depths) of two Andisols (Soil Survey Staff, 1999) derived from weathered rhyolitic tephras in central North Island, one, an Udivitrand, being much younger than the other, a Hapludand. 


\section{Materials and methods}

\subsection{Materials}

Topsoil samples from paired sites under dairy pasture farmland fertilized with superphosphate and urea, and unfertilized forest were taken from two extensive soil types derived from either Late Holocene or Late Quaternary rhyolitic (silica-rich) tephras: (1) Taupo sandy loam (an Udivitrand, Late Holocene in age), and (2) Tirau silt loam (a Hapludand, Late Quaternary in age) (Table 1). Samples for each soil comprised a composite of 50 cores, $2.5 \mathrm{~cm}$ diameter taken from $0-10 \mathrm{~cm}$ depth, on a $50 \mathrm{~m}$ transect. Rainfall was very similar at both sites (about 1600 and $1650 \mathrm{~mm}$ per annum), both were formed under native broadleaf-podocarp forest until the arrival of Polynesians around AD 1280, after which bracken fern Pteridium spp. and scrub replaced much of the forest after burning, and both are well drained (Bakker et al., 1996, Lowe and Palmer, 2005; McGlone et al., 2005).

The Taupo soil is derived from rhyolitic tephra from the Taupo eruption (AD $232 \pm$ 10, Hogg et al., 2012) and is dominated by glassy pumice clasts and glass shards, which have weathered to form about $4 \%$ clay dominated by allophane. This amount of allophanic clay is consistent with a period of weathering of only 1800 years (Hodder et al., 1990). The topsoil textures are sandy loams.

The Tirau soil is derived from intermixed, multiple tephra layers, chiefly rhyolitic in composition, derived from a very thin deposit $(\sim 1-2 \mathrm{~cm})$ from the Taupo eruption (c. AD 232) overlying a composite ( $>50 \mathrm{~cm}$ in thickness) of mainly Holocene and Late Pleistocene tephras post-dating the deposition of the Rotorua tephra (c. 15,600 calendar years ago, Lowe et al., 2013) (Table 1; Pullar and Birrell, 1973). The Tirau soil has thus had about ten times 
longer to weather through developmental upbuilding pedogenesis (Lowe and Tonkin, 2010)

than the Taupo soil, and so the topsoils have finer silt loam textures with clay contents of about $19 \%$, dominated by allophane. The volcanic glass content of the Tirau soil accordingly is lower than that of the Taupo soil (Table 1; Bakker et al., 1996).

Table 1 Characteristics of the two soil types

\begin{tabular}{|c|c|c|}
\hline Soil type & Taupo sandy loam & Tirau silt loam \\
\hline Location & $\begin{array}{l}38^{\circ} 15.7^{\prime}, 175^{\circ} 57.7^{\prime} \text { and } 38^{\circ} 16.0^{\prime}, \\
175^{\circ} 58.6^{\prime}\end{array}$ & $\begin{array}{l}37^{\circ} 57.6^{\prime}, 175^{\circ} 41.7^{\prime} \text { and } 37^{\circ} 58.0 \text {, } \\
175^{\circ} 42.3^{\prime}\end{array}$ \\
\hline $\begin{array}{l}\text { New Zealand Soil } \\
\text { Classification }^{\text {a }}\end{array}$ & Immature Orthic Pumice Soil & Typic Orthic Allophanic Soil \\
\hline Soil Taxonomy & $\begin{array}{l}\text { Typic Udivitrand, ashy/pumiceous, } \\
\text { mesic }\end{array}$ & $\begin{array}{l}\text { Typic Hapludand, medial, } \\
\text { thermic/mesic }\end{array}$ \\
\hline $\begin{array}{l}\text { Parent material and } \\
\text { age }\end{array}$ & $\begin{array}{l}\text { Taupo Tephra } \\
(\text { c. } 1718 \text { cal. yr BP })^{d}\end{array}$ & $\begin{array}{l}\text { Taupo (c. } 1718 \text { cal. yr BP) and post- } \\
\text { Rotorua rhyolitic tephras } \\
(<\text { c. } 15,600 \text { cal. yr BP) }\end{array}$ \\
\hline $\begin{array}{l}\text { Dominant } \\
\text { mineralogy } \text { (topsoil })^{-}\end{array}$ & $\begin{array}{l}\text { Low }(5 \%) \text { clay content dominated by } \\
\text { allophane. Glassy mineralogy class }\end{array}$ & $\begin{array}{l}20 \% \text { clay content dominated by } \\
\text { allophane. Abundant glass in sand } \\
\text { fraction }\end{array}$ \\
\hline Landform & Undulating crest in rolling landscape & $\begin{array}{l}20 \mathrm{~m} \text { below crest in strongly rolling } \\
\text { landscape }\end{array}$ \\
\hline Current landuse & $\begin{array}{l}\text { Unfertilized site: long-term pine forest } \\
\text { Fertilized site: pasture }\end{array}$ & $\begin{array}{l}\text { Unfertilized site: long-term pine forest } \\
\text { Fertilized site: pasture }\end{array}$ \\
\hline Topsoil morphology & $\begin{array}{l}\text { Unfertilized site: } \\
0-10 \mathrm{~cm} \text {, dark brown } 7.5 \mathrm{YR} 3 / 2 \\
\text { Fertilized site: } \\
0-17 \mathrm{~cm} \text {, very dark brown } 10 \mathrm{YR} 2 / 2 \\
\text { Both sites: } \\
\text { slightly sticky, non-plastic, moderately } \\
\text { weak, friable sandy loam }\end{array}$ & $\begin{array}{l}\text { Unfertilized site: } \\
0-18 \mathrm{~cm} \text {, dark greyish brown 10YR 3/2 } \\
\text { Fertilized site: } \\
\text { 0-15 cm, dark greyish brown 10YR 3/2 } \\
\text { Both sites: } \\
\text { non-sticky, non-plastic, weak, friable } \\
\text { loamy silt }\end{array}$ \\
\hline Fertilizer history & $\begin{array}{l}\text { Unfertilized site: } \\
\text { none known } \\
\text { Fertilized site: } \\
300 \mathrm{~kg} \mathrm{~h}^{-1} \text { superphosphate per year, } \\
\left.\text { plus regular lime ( } 1.5 \mathrm{t} \mathrm{ha}^{-1} 3 \text {-yearly }\right)\end{array}$ & $\begin{array}{l}\text { Unfertilized site: } \\
\text { none known } \\
\text { Fertilized site: } \\
700 \mathrm{~kg} \mathrm{~h}^{-1} \text { superphosphate per year, plus } \\
\text { regular lime }\end{array}$ \\
\hline
\end{tabular}

${ }^{\mathrm{a}}$ Hewitt (2010)

${ }^{\mathrm{b}}$ Soil Survey Staff (2014)

${ }^{\mathrm{c}}$ Bakker et al. (1996)

${ }^{\mathrm{d}}$ Calendar years before present $($ present $=1950$ AD) 


\subsection{Methods}

Wet chemical analyses were carried out at IANZ-accredited laboratories, Landcare Research of Palmerston North (pH-water), AgResearch of Hamilton (hot-water carbon), and Hills Laboratory of Hamilton (anaerobically mineralised nitrogen, total F, and acid extractable $\mathrm{Al}$ and $\mathrm{P}$ ), according to the Land and Soil Monitoring Manual (Hill and Sparling, 2009; Kim and Taylor, 2009). Samples were air dried at $35^{\circ} \mathrm{C}$ and sieved, with the $<2 \mathrm{~mm}$ fractions used for analyses. Nitric/hydrochloric acid digestion (US EPA 200.2) followed by ICP-MS at the trace level was used for acid extractable Al and P. Total F was analysed using the alkali-fusion/ion-selective electrode method (McQuaker and Gurney, 1982).

Visual assessments of the degree of roundness of glass shards (i.e. sharpness of the edges and corners, essentially angularity), based on Powers (1953), were undertaken using scanning electron microscopy and electron microprobe analysis at paired sites.

All the electron micrographs were acquired at Braunschweig Technical University using a Jeol 6700F cold field emission scanning electron microscope with an attached backscattered-electron detector using composition-mode. Chemical analyses were carried out using an adapted EDAX energy dispersive spectrometer system including a SiLi-detector and the Genesis software package (v 5.21). The field emission electron gun probe currents were small $\left(20 \mathrm{kV}\right.$ and current values near $\left.5^{-10} \mathrm{~A}\right)$ and the probe diameter was in a nanometre range. Areas (average of some thousand points) were analysed instead of single points to optimise the examination of glass grains to minimise loss of sodium and potassium through volatilisation during analysis (e.g. Lowe et al., 2008).

The samples were dried at $60^{\circ} \mathrm{C}$ and hand ground with an agate mortar. The resulting powder was held on a conducting carbon-pad fixed on a brass sample holder. Specimens were splutter coated with a thin conductive Au layer of 10 to $20 \mathrm{~nm}$ thickness. All the analyses were normalised to dry substance and without the non-analysed elements ( $\mathrm{Li}, \mathrm{Be}, \mathrm{B}$ 
etc.). All the SEM/EDX combination quantifications of glass have about 5\% instrument error because analysis are of non-perfect surfaces with inhomogenities and other small particles in the vicinity. Thus, the results are presented to only two significant places.

\section{Results}

Selected analytical data from the paired sites are presented in Table 2. Compared with the background sites, long-term fertilizer application has resulted in increased P, F, and acid-extractable $\mathrm{Al}$, whereas the addition of lime has increased the $\mathrm{pH}$. Because $\mathrm{pH}$ has increased, the increase in acid-extractable Al clearly cannot be attributed to a lowering of the $\mathrm{pH}$.

Table 2 Selected analytical data from the paired unfertilized and fertilized sites

\begin{tabular}{|c|c|c|c|}
\hline Analysis & Site & $\begin{array}{r}\text { Taupo sandy loam } \\
\text { (Udivitrand) }\end{array}$ & $\begin{array}{r}\text { Tirau silt loam } \\
\text { (Hapludand) }\end{array}$ \\
\hline \multirow[t]{2}{*}{ Acid extractable $\mathrm{P} / \mathrm{mg} \mathrm{kg}^{-1}$} & Unfertilized $^{\mathrm{a}}$ & 290 & 610 \\
\hline & Fertilized $^{\mathrm{b}}$ & 2600 & 2800 \\
\hline \multirow[t]{2}{*}{ Total F / $\mathrm{mg} \mathrm{kg}^{-1}$} & Unfertilized & 240 & 250 \\
\hline & Fertilized & 690 & 570 \\
\hline \multirow{2}{*}{$\begin{array}{l}\text { Acid extractable } \mathrm{Al} / \mathrm{mg} \mathrm{kg}^{-} \\
-\end{array}$} & Unfertilized & 9700 & 19000 \\
\hline & Fertilized & 8900 & 36000 \\
\hline \multirow[t]{2}{*}{$\mathrm{pH}$} & Unfertilized & 5.3 & 5.3 \\
\hline & Fertilized & 5.7 & 6.2 \\
\hline \multirow[t]{2}{*}{ Total C (\%) } & Unfertilized & 7.8 & 4.3 \\
\hline & Fertilized & 10.6 & 10.8 \\
\hline \multirow{2}{*}{$\begin{array}{l}\text { Anaerobically } \\
\text { mineralised } \mathrm{N} / \mathrm{mg} \mathrm{kg}^{-1}\end{array}$} & Unfertilized & 95 & 80 \\
\hline & Fertilized & 210 & 200 \\
\hline \multirow{2}{*}{$\begin{array}{l}\text { Hot water carbon } / \mathrm{mg} \mathrm{kg}^{-} \\
\end{array}$} & Unfertilized & 3150 & 3050 \\
\hline & Fertilized & 6250 & 6350 \\
\hline
\end{tabular}

aine forest (background)

bPasture

The older and longer-fertilized soils showed a decrease in the average size of the glass shards: the average grain size of the Taupo-soil shards was reduced after fertilization from 39 to $31 \mu \mathrm{m}$ in diameter, and that of the Tirau-soil shards was reduced after fertilization from 37 to $24 \mu \mathrm{m}$ (Table 3). Most shards were angular or very angular (i.e. grain edges were sharpest) 
in the unfertilized Taupo soil, while those of the older Tirau soil were sub-angular or sub-

rounded (Table 3), and pitting in shards was present for the fertilized Tirau soil (Figs. 1-2), consistent with phosphate fertilizer-induced accelerated dissolution imposed over natural weathering (cf. Hodder et al., 1990, 1991).

Table 3 Comparison of glass-shard sizes for samples from fertilized and unfertilized soils, and roundness classes (range 0 to 6) of Powers (1953), and presence of neogenic silica polymorphs

\begin{tabular}{|c|l|l|l|l|l|l|l|l|}
\hline & \multicolumn{3}{|l|}{ Taupo sandy loam (Udivitrand) } & \multicolumn{3}{l|}{ Tirau silt loam (Hapludand) } \\
\cline { 2 - 8 } & $\begin{array}{l}\text { Average } \\
\mu \mathrm{m}\end{array}$ & $\begin{array}{l}\text { Median } \\
\mu \mathrm{m}\end{array}$ & $\begin{array}{l}\text { Range } \\
\mu \mathrm{m}\end{array}$ & $n$ & $\begin{array}{l}\text { Average } \\
\mu \mathrm{m}\end{array}$ & $\begin{array}{l}\text { Median } \\
\mu \mathrm{m}\end{array}$ & $\begin{array}{l}\text { Range } \\
\mu \mathrm{m}\end{array}$ & $n$ \\
\hline Unfertilized & 39 & 33 & $12-231$ & 104 & 37 & 25 & $22-252$ & 101 \\
\hline Fertilized & 31 & $7-246$ & 102 & 24 & 22 & $8-94$ & 100 \\
\hline Roundness & $\begin{array}{l}\text { Mainly classes 0 \& 1 (very angular to } \\
\text { angular) with class 1 predominant in } \\
\text { fertilized soil }\end{array}$ & $\begin{array}{l}\text { Mainly classes 2 \& 3 (subangular to } \\
\text { subrounded) with class 3, and pitting, } \\
\text { predominant in fertilized soil }\end{array}$ \\
\hline $\begin{array}{c}\text { Neogenic } \\
\text { SiO } \\
\text { polymorph }\end{array}$ & $\begin{array}{l}\text { Not present in either unfertilized or } \\
\text { fertilized soils }\end{array}$ & \multicolumn{2}{l|}{$\begin{array}{l}\text { Present in fertilized soil only } \\
\end{array}$} \\
\hline
\end{tabular}




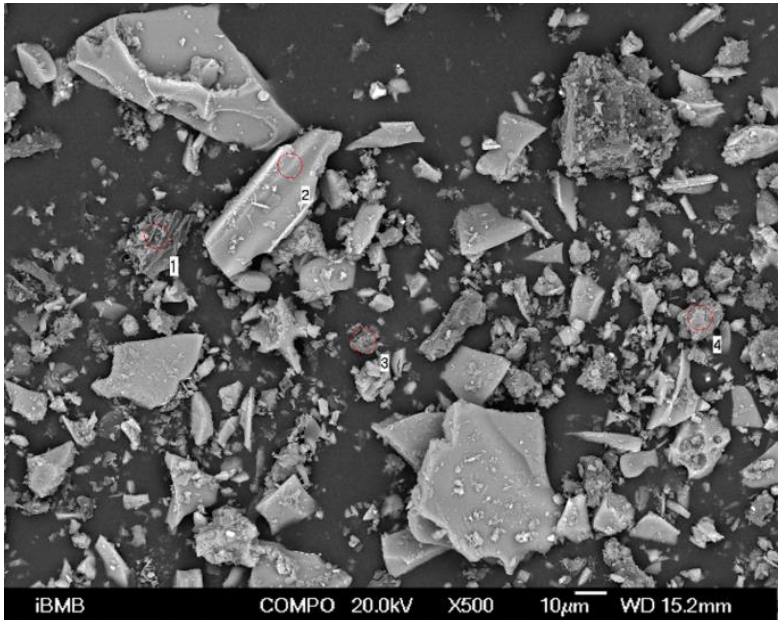

A. Taupo sandy loam, unfertilized

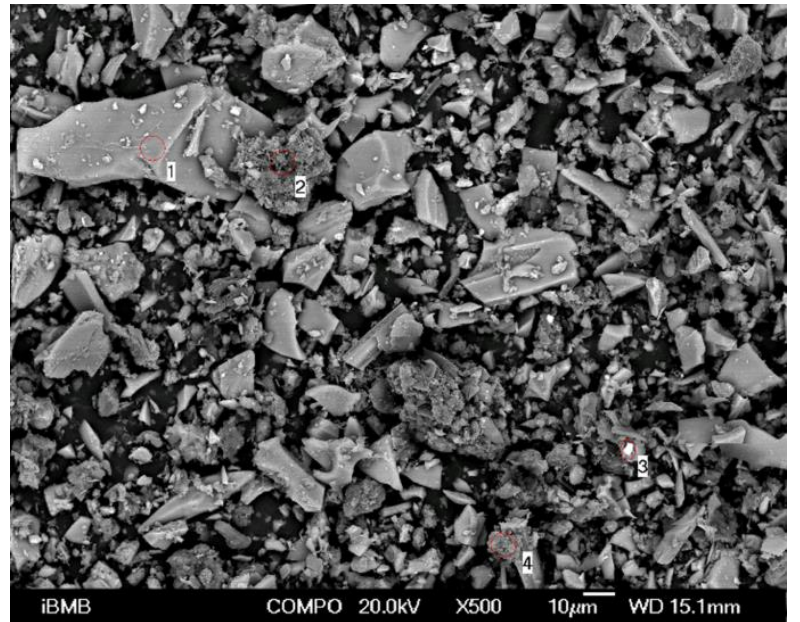

B. Taupo sandy loam, fertilized

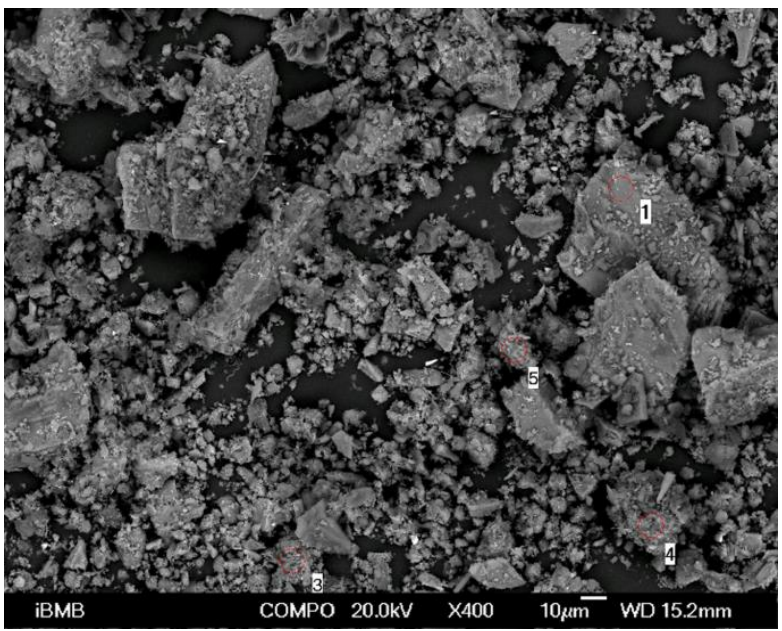

C. Tirau silt loam, unfertilized

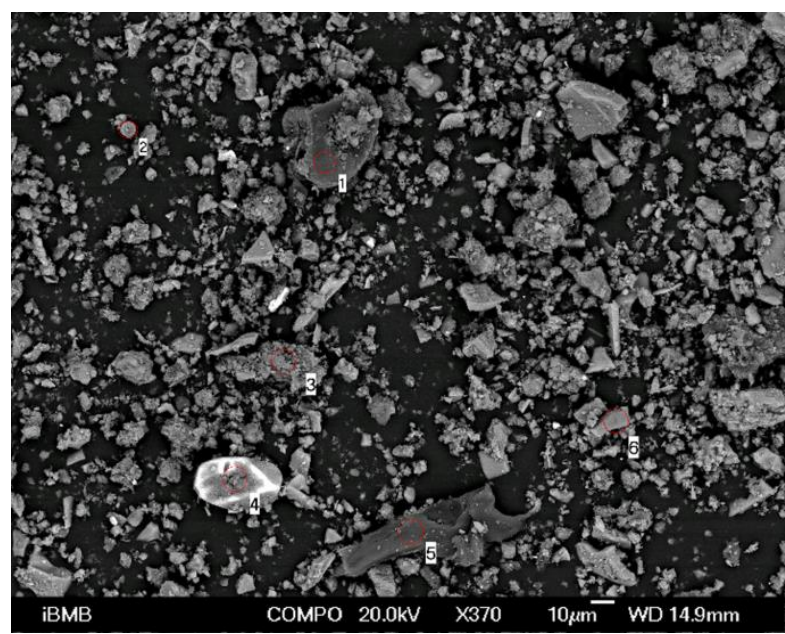

D. Tirau silt loam, fertilized

Fig. 1 Electron micrographs of glass shards from the four soils ( $<2 \mathrm{~mm}$ fractions). Also present in small amounts are crystals or crystal fragments (mineral grains including felsic and ferromagnesian minerals, and Fe-Ti oxides), and clay aggregates. The numbers represent microprobe analysis sites 


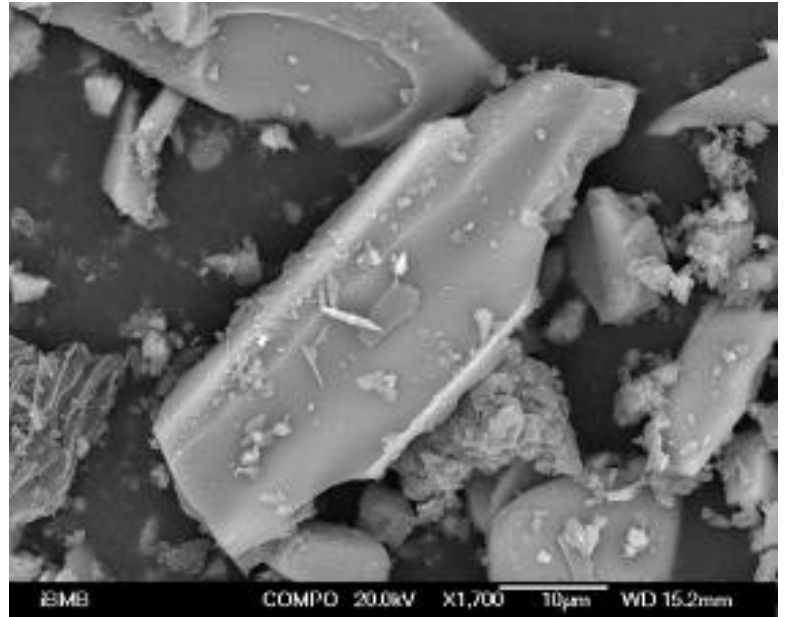

A. Taupo sandy loam, unfertilized, very angular shards (class 0)

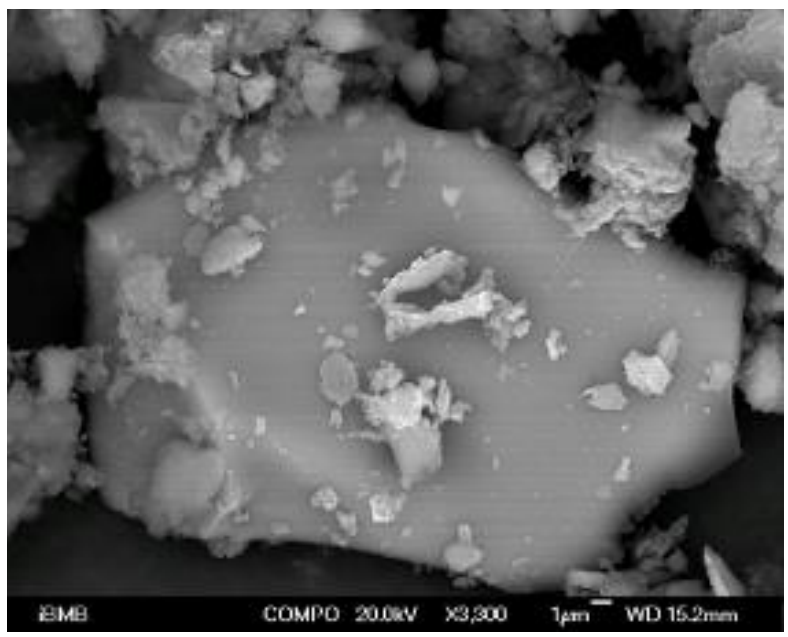

C. Tirau silt loam, unfertilized, subangular shard (class 2)

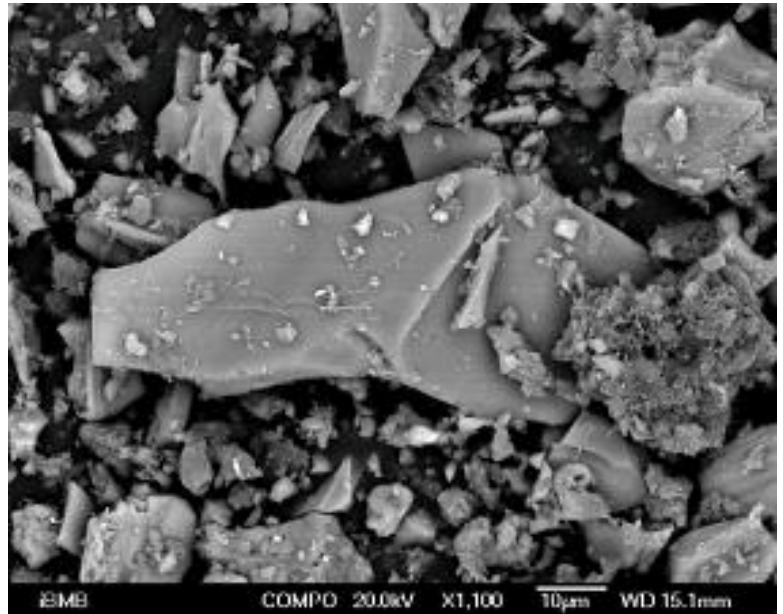

B. Taupo sandy loam, fertilized, angular shards (class 1)

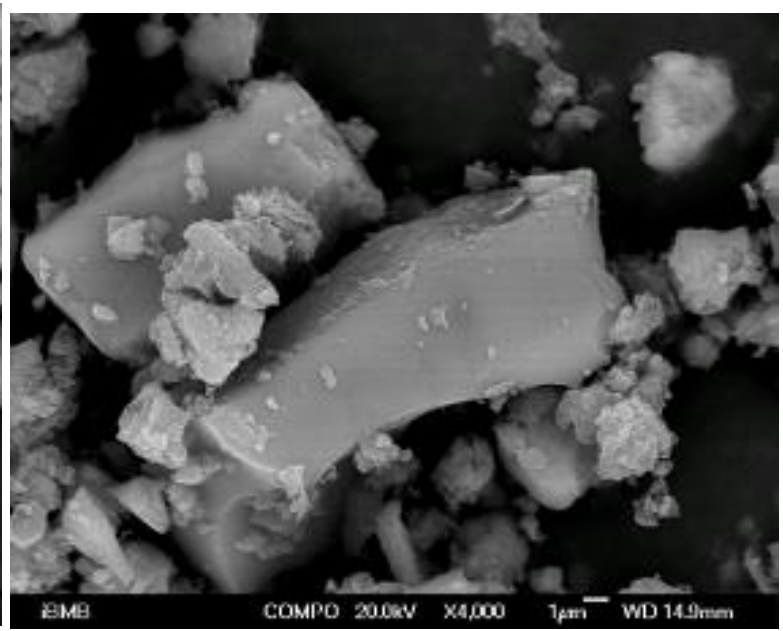

D. Tirau silt loam, fertilized, subrounded shards (class 3) with pits

Fig. 2 Micrographs of representative glass shards from the four soils showing differences in roundness classes (Powers 1953).

Electron microprobe analyses $(n=22)$ of major elements for the unfertilised and fertilised Taupo soils are consistent with those obtained previously on glass from Taupo and other rhyolitic tephras in New Zealand (e.g. Gehrels et al., 2006; Lowe et al., 2008), with normalized mean $( \pm 1 \mathrm{sd})$ data for the most abundant oxides as follows: $\mathrm{SiO}_{2} 72.5 \pm 1.4 \mathrm{wt} \%$; $\mathrm{Al}_{2} \mathrm{O}_{3} 13.3 \pm 0.6 \mathrm{wt} \% ; \mathrm{TiO}_{2} 0.3 \pm 0.1 \mathrm{wt} \% ; \mathrm{FeO} 3.0 \pm 0.8 \mathrm{wt} \%$ (total iron expressed as $\mathrm{FeO}$ ); $\mathrm{MnO} 0.2 \pm 0.1 \mathrm{wt} \% ; \mathrm{MgO} 0.6 \pm 0.1 \mathrm{wt} \% ; \mathrm{CaO} 1.9 \pm 0.4 \mathrm{wt} \% ; \mathrm{Na}_{2} \mathrm{O} 3.7 \pm 0.8 \mathrm{wt} \%$; and $\mathrm{K}_{2} \mathrm{O}$ $4.6 \pm 0.9 \mathrm{wt} \%$. No glass shards large enough for satisfactory microprobe analysis were found 
in the fertilized Tirau soil. The analyses showed a peak where F would be expected, but it was related in size to $\mathrm{Fe}$ and was attributed to Fe interference.

Silica polymorphs $\left(\mathrm{SiO}_{2}\right)$ were identified in the Tirau fertilized soil (Fig. 3), but not in samples from the other soils (Table 3).

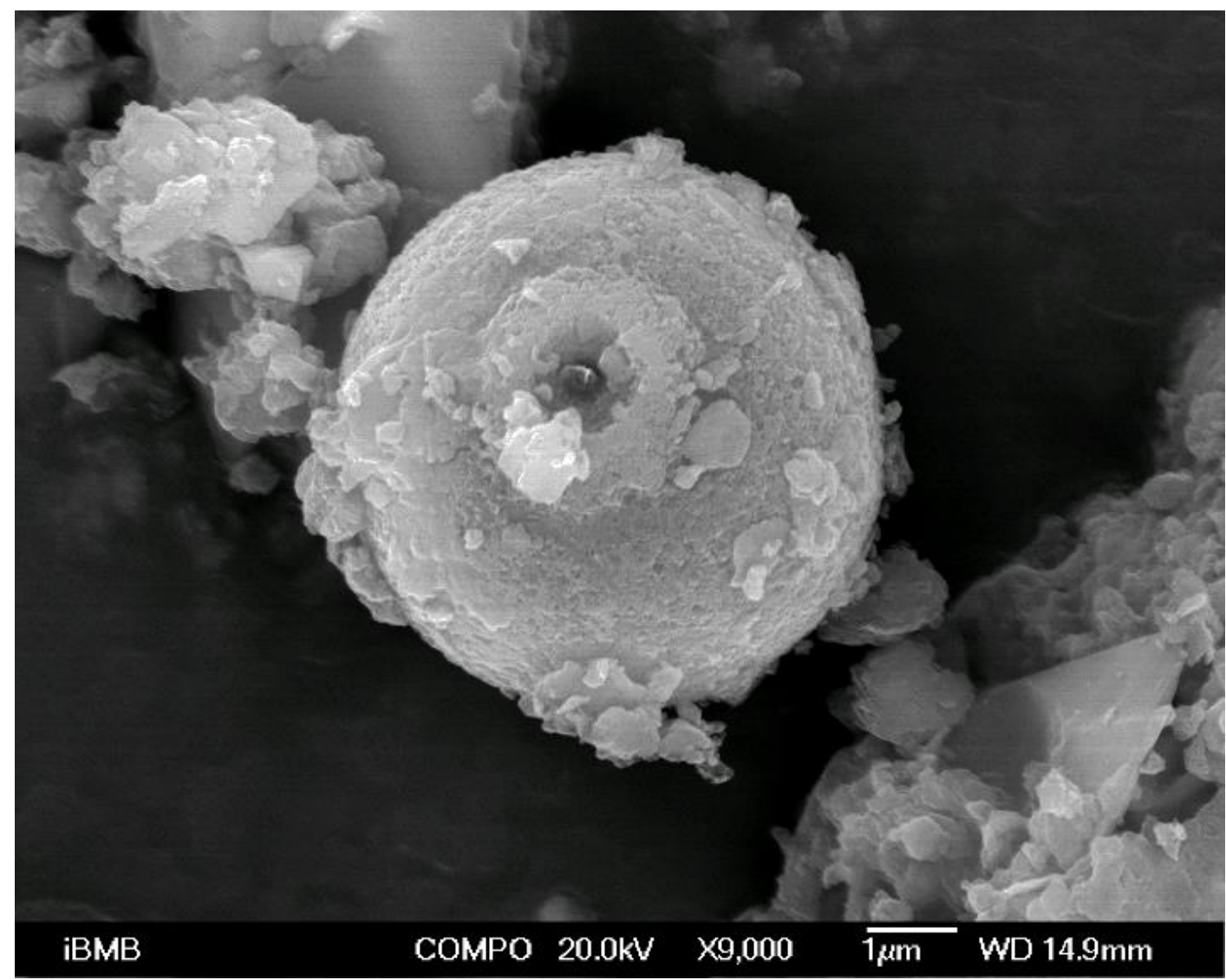

Fig. 3 Example of neogenic silica in the Tirau silt loam, fertilized soil

\section{Discussion}

4.1. Enhanced dissolution of volcanic glass, induced by the addition of phosphate fertilizer

The weathering of volcanic glass and the formation of comminuted residues and clay minerals have been previously reported by Bakker et al. (1996) in a micromorphological 
study that included examination of both the Taupo and Tirau soils. They found pumiceous glass fragments decreased in amount and size towards the soil surface, and that these fragments were altered with some of the vesicles broken or opened and filled with noncrystalline isotropic, i.e. nanocrystalline, clay-sized material. Our study shows enhanced dissolution of volcanic glass, induced by the addition of phosphate fertilizer, is an additional process to that of natural chemical weathering (by hydrolysis) and clay-mineral synthesis. The effects of chemical weathering are seen in plant production of acids and chelating ligands to accelerate chemical alteration of soil minerals and compounds (Churchman and Lowe, 2012; Sparks, 2012). Alekseeva et al. (2011) reported soil acidification under a tea plantation accelerated not only the transformation of silicate minerals, but also changes in ferromagnetic minerals in the soil. Although acidification enhances the mobility of many metal cations, Taylor and Kim (2009) found the acid extractable fraction was enhanced only in some metals and not in $\mathrm{Cr}$ or $\mathrm{Fe}$, suggesting an additional mechanism is occurring. $\mathrm{F}$ is known as an aggressive extractant for $\mathrm{Al}$ from within the soil matrix and enhances aluminosilicate dissolution rates (Elrashidi and Lindsay, 1987).

Dissolution rates of glass increase monotonically with increasing fluoride concentration because of the formation of Al-fluoride complexes, which decrease the activity of $\mathrm{Al}^{3+}$ (Wolff-Boenisch et al., 2004). In addition, Sigfusson et al. (2008) showed that the chemical weathering rates of Andisols were influenced by the external supply of anions, such as $\mathrm{F}$, capable of complexing $\mathrm{Al}^{3+}$. Consequently, it is not surprising that a similar process takes place around a phosphate fertilizer granule that supplies phosphoric acid and ligands such as $\mathrm{F}^{-}$. The importance of $\mathrm{F}$ is emphasised. Acidity alone would dissolve acid-soluble compounds and would not explain the increase in acid-soluble Al seen by Taylor et al. (2012) and Taylor and Kim (2009). Also, the acidity around a phosphate fertilizer granule is temporary as $\mathrm{PO}_{4}{ }^{3-}$ exchanges with $\mathrm{OH}^{-}$on the soil matrix. Tuttle et al. (2009) reported that 
neutralisation of the weathering solution from a shale-derived soil in streams and groundwater resulted in elements being adsorbed and precipitated.

The formation of Al-fluoride complexes and subsequent decrease in $\mathrm{Al}^{3+}$ activity around a phosphate fertilizer granule pushes the equilibrium in favour of more dealumination and probably more desilication. As loading of the pore water increases and $\mathrm{pH}$ increases (with $\mathrm{PO}_{4}{ }^{3-}$ sorption), the complexes become increasingly insoluble. Thus, increased amounts of $\mathrm{Si}$ and $\mathrm{Al}$ are available for the neogenesis of (acid soluble) secondary minerals, or $\mathrm{Al}$ could occupy exchange sites on mineral surfaces (Pawluk and Dudas, 1978), or both. Al remains in the surface horizon but is now readily acid soluble.

\subsection{Reactions with soil organic matter}

As with reactions with $\mathrm{F}$, organic matter can form complexes with $\mathrm{Al}$ and may have a role in regulating $\mathrm{Al}$ release rates in natural weathering and dissolution of glass and minerals in tephras (Dahlgren and Walker, 1993; Nanzyo, 2002; McDaniel et al., 2012) - for example, speciating $\mathrm{Al}^{3+}$ with oxalate increased dissolution rates in basaltic glass (Sigfusson et al., 2008). In our study, significant amounts of organic matter, as measured as total $\mathrm{C}$, were present in the soils at both the fertilized and unfertilized sites but considerably more was present at the fertilized sites (Table 2). Also, leaching of major base cations by dissolved organic matter has been reported by Egli et al. (2008) and Antweiler and Drever (1983), and $\mathrm{Mg}$ and $\mathrm{Na}$ depletion at the fertilized sites compared with the unfertilized sites was observed by Taylor and Kim (2009). Calcium and K were not depleted because of lime and fertilizer additions.

It is likely both $\mathrm{F}^{-}$and organic matter form complexes with $\mathrm{Al}$, influencing chemical weathering rates (Ugolini et al., 1988). Organic and fluoride complexes were the dominant forms of $\mathrm{Al}$ in all soil solutions and through-flow from hardwood and conifer sites in the 
Adirondack Mountains, New York (David and Driscoll, 1984), while Al-fluoride complexes were the predominant fraction of labile $\mathrm{Al}$ in Adirondack surface waters (Driscoll et al., 1987), even though these sites are unlikely to receive F-containing fertilizers. The addition of $\mathrm{F}$ in fertilizer is likely to increase the proportion of $\mathrm{Al}$ as fluoride complexes.

\subsection{Formation of clay minerals}

A consequence of enhanced weathering may be enhanced formation of clay minerals through the redistribution of Al. This is because the dissolution of volcanic glass plays an important role in formation and transformation processes and as a cation supplier (Kawano et al., 1997). This process redistributes constituents originally bound within the glass, such as base cations, trace elements, and Al, potentially increasing their mobility and bioavailability. The redistribution of Al may aid the formation of clay minerals, such as allophane or halloysite. Where silica is rapidly removed by leaching, allophane formation is favoured; where silica activity in soil solution is high $\left(>\sim 10 \mathrm{mg} \mathrm{L}^{-1}\right)$, halloysite forms in preference to allophane (Parfitt et al., 1983, 1984; Singleton et al., 1989; Parfitt, 1990, 2009; Churchman and Lowe, 2012).

\subsection{Possible biochemical weathering of volcanic glass}

Alternatively, enhanced biochemical weathering could be caused by the increased activity of microorganisms as indicated by the increased anaerobically mineralised $\mathrm{N}$ and hot-water carbon analyses (Table 2). It might be that microbial activity is strongly increased by the addition of P-fertilizer and, as a consequence, biochemical weathering of the glass is increased. Although microbially-derived etch pits and biogenic grooves reported in Staudigel et al. (1995) and Thorseth et al. (1995) were not seen in our samples, that some of dissolution was due to microbes cannot be ruled out (cf. Cockell et al., 2009). If microorganisms assist in 
reducing angularity, then the hypothesis still holds in that the addition of fertilizers, arguably, could enhance microbial activity.

Ploughing of farmland can also enhance microbial activity by making labile soil organic matter more available (e.g. see Goh, 2004). In rhyolitic glass, there are also potential nutrients, such as $\mathrm{K}, \mathrm{Mg}$, and $\mathrm{Ca}$, which can, if released, increase microbial activity. However, biological activity, as measured by anaerobically mineralized $\mathrm{N}$ in Taylor and Kim (2009), followed soil organic $\mathrm{C}$ concentration $(r=0.545)$ rather than being a consequence of fertilizer application or not.

\subsection{Silica polymorphs}

Another consideration is the presence of neogenetic silica polymorphs in the topsoil of the fertilized Tirau soil alone. Annual rainfall at all sites is relatively high (average $1600-1650 \mathrm{~mm}$ ) and leaching should result in desilication of the topsoil, with silica reprecipitated (or combined with $\mathrm{Al}$ ) deeper in the soil environment according to the silicaleaching model established for soils developed on tephras described above (e.g. Lowe, 1986, 1995; Singleton et al., 1989). An explanation for the contrasting observation - the precipitation of silica polymorphs despite high rainfall - may relate to the seasonality of fertilizer application. Most phosphate fertilizer is applied in the Waikato region annually in late spring when soil through-flow is diminishing. Although rainfall averages about 100 $\mathrm{mm} / \mathrm{month}$ over spring-summer, drainage through to the subsoil does not occur except in extreme weather events, i.e. soil solution movement is minor or static. Thus, the soil remains moist for a period long enough for the dissolution of volcanic glass (and possibly other alumina-silicates), the formation of Al-humus complexes, and the precipitation of silica in the form of silica polymorphs. In addition, the supersaturation of silica by surface evaporation and plant transpiration in the A horizon, and thus potential for its precipitation, would 
potentially be at a maximum during late summer or early autumn when the soil generally is driest (Lowe, 1986; Drees et al., 1989).

An alternative mechanism for the formation of the silica polymorphs could be through the uptake and biocycling of Si by plants (Lowe, 1986; Henriet et al., 2008; Churchman and Lowe, 2012; Clymans et al., 2015). Farmer et al. (2005) postulated that plant phytoliths provide a sink, hence short-term nutrient uplift, for Si from soil solutions during the growing season that is released back to solutions during winter and spring. This mechanism could be important for increased cultivation safety for growing Si-accumulating plants (e.g. rice, sugar cane, and sorghum).

\subsection{Elemental fluxes}

The hydration and hydrolysis of glass should result in fluxes of $\mathrm{Al}, \mathrm{Si}$, base cations, and traces of other elements from the glass into interstitial pore waters (Hodder et al., 1991, 1996). Proton exchange and the release of base cations should result in acid buffering and contribute to the very rapid precipitation of secondary minerals from such solutions as well as replacement of glass shards by new secondary minerals (Hodder et al., 1990; Dahlgren et al. 2004; Churchman and Lowe, 2012). Consistent with such fluxes, acid-recoverable concentrations of several trace elements that were normally retained inside residual phases of aluminosilicates were shown by Taylor and Kim (2009) to be also significantly higher in fertilized than in nonfertilized soils. These include (with enrichment-to-background factors) $\mathrm{Li}$ (2.5), $\mathrm{La}(2.1), \mathrm{Mn}$ (1.5), and $\mathrm{Ag}, \mathrm{Bi}, \mathrm{Mo}, \mathrm{Sn}$, and $\mathrm{Tl}$ (1.4). Also, this process may have contributed one-quarter of the observed increase in acid-recoverable $\mathrm{U}$ in Taylor and Kim (2009).

Another consequence of enhanced weathering may be enhanced leaching of the more mobile elements and concentration of relatively immobile elements, such as $\mathrm{Ti}, \mathrm{Cr}$, and $\mathrm{V}$. 
Generally, larger cations, such as Al, would be expected to remain fixed within the soil profile, although these can be redistributed to lower horizons, while smaller cations, such as $\mathrm{Ca}, \mathrm{Na}$, and Sr, may be preferentially leached (Churchman and Lowe, 2012). Similarly, lighter isotopes may be preferentially leached and the chemical signature of the soil may be changed. As chemical and isotopic signatures are ultimately transferred to the sedimentary record, changes in soil elemental and isotopic composition may affect the element geochemistry and mineralogy of sediments.

\subsection{Implications for soil and land management}

In general, Andisols are noted for their distinctive physical properties such as high water-holding capacity, free drainage, low bulk density and high porosity and hence good aeration, stable aggregation, friability, and good tilth (e.g. Ugolini and Dahlgren, 2002; McDaniel et al., 2012; Yuan and Wada, 2012). These features are manifest in Andisols in New Zealand, including the Tirau and Taupo soils (Parfitt et al., 1981; Allbrook, 1985; Neall, 2006; Lowe and Palmer, 2005; Hewitt, 2010). Consequently, they are usually excellent media for seedling emergence and root growth and proliferation. It should be emphasized, however, that these properties may be altered through management (Candan and Broquen, 2009; Neall, 2006; McDaniel et al., 2012). From our study, several implications for soil management and health emerge as a consequence of the accelerated weathering. For example, some trace elements, such as Co, are already at levels below optimum for animal health in these soils (e.g. Cornforth, 1998; Lowe et al., 2014) and increased leaching of these could reduce the efficiency of corrective fertilizer additions. Increased direct dosing of animals with essential trace elements may be required in the future.

Other implications for soil management include changes in soil permeability and water storage capacity. Loss of mass may lead to increased porosity of the soil and enhanced 
permeability, if it is undisturbed by further cultivation. Tuttle and Breit (2009) reported enhanced permeability because of a $14 \%$ loss of the original mass in parent material for a shale-derived soil. Conversely, precipitation of clays within pore spaces may reduce soil permeability but increase water storage. Changes in porosity are also likely to cause changes in surface area and capacity to store cations and anions (Notario et al., 1995).

At a global scale, there may be a significant feedback mechanism between climate and weathering processes. Enhanced weathering could result in enhanced removal of $\mathrm{CO}_{2}$ from the atmosphere, as soil carbon derived ultimately from photosynthesis is converted into dissolved $\mathrm{HCO}_{3}{ }^{-}$(Berner, 1997). Also, weathering releases divalent cations to the ocean via groundwater and riverine transport. Once there, divalent cations promoting the drawdown of $\mathrm{CO}_{2}$ from the atmosphere by the precipitation and subsequent burial of carbonate minerals (Gislason et al., 2009). If the enhancement of weathering is significant, it may provide some mitigation for climate change.

It is often taken for granted that soil processes over relatively short time spans, i.e. decades, will continue to behave as they have in the past. However, the impact of a "new" development may change processes and hence soil properties and soil functioning, potentially leading to a threat to food security. Given that this enhanced weathering has been identified in some of the most extensive farming areas of New Zealand, there is some urgency in ascertaining its effects on soil properties in greater depth.

\section{Conclusions}

The hypothesis tested in this study is that the addition of F-containing phosphate fertilizers enhances the dissolution of volcanic glass, as shown by a marked decrease in shard size and 
angularity, and an increase in dissolution pitting on shard surfaces, through production of phosphoric acid and $\mathrm{F}^{-}$-chelating ligands increasing amounts of $\mathrm{Si}$ and $\mathrm{Al}$ available for neogenesis. Al and Si may subsequently coprecipitate as secondary minerals, such as allophane. However, neogenic silica may form where Al activity is low through the formation of Al-fluoride or Al-humus complexes, coupled possibly with seasonal climatic effects.

The occurrence of neogenic silica in topsoil of the fertilized Tirau soil, when the annual rainfall indicated leaching should result in desilication of the topsoil and the reprecipitation of silica deeper in the soil, could be explained by the seasonality of fertilizer application and the spring-summer climate, where the soil remains moist for a period long enough in spring for the dissolution of volcanic glass (and possibly other alumina-silicates), the formation of Al-humus complexes, and then the precipitation of silica in late summer or early autumn when conditions are driest.

As this enhanced weathering has been identified in some of the major farming areas of New Zealand, there is a growing need to ascertain further its effects on soil properties and impacts on soil and land management.

\section{Acknowledgments}

We thank the farmers for allowing us to sample on their land, Wim Rijkse for the site descriptions, and laboratory staff at Landcare Research, AgResearch and Hill Laboratories for analysing the soils. Two anonymous reviewers and the editor are also thanked for their valuable comments. Funding for travel to Germany for M. Taylor was provided by the Royal Society of New Zealand International Mobility Fund contract FRG 11-40. 


\section{References}

Alekseeva, T., Alekseeva, A., Xu, R.-K., Zhao, A.-Z., Kalinin, P., 2011. Effect of soil acidification induced by a tea plantation on chemical and mineralogical properties of Alfisols in eastern China. Environ. Geochem. Health 33(2), 137-148.

Allbrook, R.F., 1985. The effect of allophane on soil properties. Applied Clay Science 1, 6569.

Antweiler, R.C., Drever, J.I., 1983. The weathering of a late Tertiary volcanic ash: importance of organic solutes. Geochim. Cosmochim. Ac. 47(3), 623-629.

Bakker, L., Lowe, D.J., Jongmans, A.G., 1996. A micromorphological study of pedogenic processes in an evolutionary soil sequence formed on Late Quaternary rhyolitic tephra deposits, North Island, New Zealand. Quatern. Int. 34-36, 246-261.

Barak, P., Jobe, B. O., Krueger, A. R., Peterson, L. A., Laird, D. A., 1997. Effects of longterm soil acidification due to nitrogen fertilizer inputs in Wisconsin. Plant and Soil, 197(1), 61-69.

Berner, R.A., 1997. The rise of plants and their effect on weathering and atmospheric $\mathrm{CO}_{2}$. Science 276, 544-546.

Bolan, N. S., Hedley, M. J., White, R. E., 1991. Processes of soil acidification during nitrogen cycling with emphasis on legume based pastures. Plant and Soil, 134(1), 53-63.

Bouman, O. T., Curtin, D., Campbell, C. A., Biederbeck, V. O., Ukrainetz, H., 1995. Soil acidification from long-term use of anhydrous ammonia and urea. Soil Science Society of America Journal 59(5), 1488-1494.

Candan, F., Broquen, P., 2009. Aggregate stability and related properties in NW Patagonian Andisols. Geoderma 154, 42-47. 
Churchman, G., Lowe, D.J., 2012. Alteration, formation, and occurrence of minerals in soils, in: Huang, P., Li Y. and Sumner M. (Eds.), Handbook of Soil Sciences. 2nd edition. Vol. 1: Properties and Processes. CRC Press Boca Raton, FL, pp. 20.1-20.72.

Clymans, W., Barão, L., Van der Putten, N., Wastegård, S., Gísladóttir, G., Björck, S., Moine, B., Struyf, E., Conley, D.J., 2015. The contribution of tephra constituents during biogenic silica determination: implications for soil and paleoecological studies. Biogeosciences Discussion 12, 3505-3545.

Cockell, C.S., Olsson-Francis, I.A., Herrerai, A., Meunier, A., 2009. Alteration textures in terrestrial volcanic glass and the associated bacterial community. Geobiology 7, 50-65.

Cornforth, I., 1998. Practical Soil Management. Lincoln University Press, Canterbury, and Whitirea Publishing, Wellington, New Zealand.

Cronin S., Manoharan, V., Hedley, M. J., Loganathan, P., 2000. Fluoride: a review of its fate, bioavailability, and risks of fluorosis in grazed-pasture systems in New Zealand. New Zeal. J. Agri. Res. 43(3), 295-321.

Dahlgren, R., Walker, W., 1993. Aluminum release rates from selected Spodosol Bs horizons - effect of pH and solid-phase aluminium pools. Geochim. Cosmochim. Ac. 57(1), 57-66.

Dahlgren, R. A., Saigusa, M., Ugolini, F.C., 2004. The nature, properties, and management of volcanic soils. Adv. Agron. 82, 113-182.

David, M.B., Driscoll, C.T., 1984. Aluminum speciation and equilibria in soil solutions of a Haplorthod in the Adirondack Mountains (New York, USA). Geoderma 33(4), 297-318.

Declercq, J., Diedrich, T., Perrot, M., Gislason, S., Oelkers, E., 2013. Experimental determination of rhyolitic glass dissolution rates at $40-200 \mathrm{C}$ and $2<\mathrm{pH}<10.1$. Geochimi. Cosmochimi. Ac. 100, 251-263.

Drees, L. R., Wilding, L. P., Smeck, N. E., Senkayi, A. L., 1989. Silica in soils: quartz and disordered silica polymorphs, in: Dixon, J. B., Weed, S. B. (Eds.), Minerals in Soil 
Environments, 2nd edition. Madison: Soil Science Society of America Book Series No. 1, pp. 913-974.

Driscoll, C.T., Yatsko, C.P., Unangst, F.J., 1987. Longitudinal and temporal trends in the water chemistry of the North Branch of the Moose River. Biogeochemistry 3(1-3), 37-61.

Egli, M. et al., 2008. Clay minerals, oxyhydroxide formation, element leaching and humus development in volcanic soils. Geoderma 143(1), 101-114.

Egli, M., Dürrenberger, S., Fitze, P., 2004. Spatio-temporal behaviour and mass balance of fluorine in forest soils near an aluminium smelting plant: short-and long-term aspects. Environmental Pollution 129(2), 195-207.

Elrashidi, M., Lindsay, W., 1987. Effect of fluoride on pH, organic matter and solubility of elements in soils. Environ. Poll. 47(2), 123-133.

Farmer, V. C., Delbos, E., Miller, J. D., 2005. The role of phytolith formation and dissolution in controlling concentrations of silica in soil solutions and streams. Geoderma 127, 71-79.

Gehrels, M., Lowe, D., Hazell, Z., Newnham, R., 2006. A continuous 5300-yr Holocene cryptotephrostratigraphic record from northern New Zealand and implications for tephrochronology and volcanic hazard assessment. Holocene 16, 173-187.

Gislason, S., Oelkers, E., 2003. Mechanism, rates, and consequences of basaltic glass dissolution: II. An experimental study of the dissolution rates of basaltic glass as a function of $\mathrm{pH}$ and temperature. Geochim. Cosmochim. Ac. 67(20), 3817-3832.

Gislason, S.R., Oelkers, E.H., Eiriksdottir, E.S., Kardjilov, I., Gisladottir, G., Sigfusson, B., Snorrason, A., Elefsen, S., Hardardottir, J., Torssander, P., Oskarsson, N., 2009. Direct evidence of the feedback between climate and weathering. Earth Plan. Sc. Lett. 277(1), 213-222.

Gjems, O., 1970. Mineralogical composition and pedogenic weathering of the clay fraction in podzol soil profiles in Zalesine, Yugoslavia. Soil Science 110(4), 237-243. 
Goh, K.M., 2004. Carbon sequestration and stabilization in soils: implications for soil productivity and climate change. Soil Science and Plant Nutrition 50, 467-476.

Goldberg, S., Sposito, G., 1985. On the mechanism of specific phosphate adsorption by hydroxylated mineral surfaces: a review. Communications in Soil Science and Plant Analysis 16(8), 801-821.

Henriet, C., De Jaeger, N., Dore, M., Opfergelt, S., Delvaux, B., 2008. The reserve of weatherable primary silicates impacts the accumulation of biogenic silicon in volcanic ash soils. Biogeochemistry 90, 209-223.

Hewitt, A.E., 2010. New Zealand Soil Classification, $3^{\text {rd }}$ edition. Landcare Research Scientific Series No. 1. Lincoln, New Zealand: Manaaki Whenua Press.

Hill, R. B., Sparling, G. P., 2009. Soil quality monitoring, in: Land and Soil Monitoring: a Guide for SoE and Regional Council Reporting. Land Monitoring Forum, Waikato Regional Council, Hamilton, New Zealand, pp. 27-88.

Hiradate, S., Wada, S. I., 2005. Weathering processes of volcanic glass to allophane determined by ${ }^{27} \mathrm{Al}$ and ${ }^{29} \mathrm{Si}$ solid-state NMR. Clay. Clay Miner. 53(4): 401-408.

Hodder, A.P.W., Green, B.E. and Lowe, D.J., 1990. A two-stage model for the formation of clay minerals from tephra-derived volcanic glass. Clay Miner. 25(3), 313-327.

Hodder, A.P.W., de Lange, P.J.., Lowe, D.J., 1991. Dissolution and depletion of ferromagnesian minerals from Holocene tephra layers in an acid bog, New Zealand, and implications for tephra correlation. J. Quaternary Sci. 6(3), 195-208.

Hodder, A.P.W., Naish, T., Lowe, D.J., 1996. Towards an understanding of thermodynamic and kinetic controls on the formation of clay minerals from volcanic glass under various environmental condition, in: S. Pandalai (Ed.), Recent Research Developments in Chemical Geology. Research Signpost, Trivandrum, India, pp.1-11. 
Hogg, A., Lowe, D.J., Palmer, J., Boswijk, G., Ramsey, C., 2012. Revised calendar date for the Taupo eruption derived by ${ }^{14} \mathrm{C}$ wiggle-matching using a New Zealand kauri $14 \mathrm{C}$ calibration data set. The Holocrene 22(4), 439-449.

Jackson, M. L., Hseung, Y., Corey, R. B., Evans, E. J., Heuvel, R. C., 1952. Weathering sequence of clay-size minerals in soils and sediments. Soil Science Society of America Journal 16(1), 3-6.

Kawano, M., Tomita, K., Shinohara, Y., 1997. Analytical electron microscopic study of the noncrystalline products formed at early weathering stages of volcanic glass. Clay. Clay Miner. 45(3), 440-447.

Kim, N. D., Taylor, M. D., 2009. Trace element monitoring, in: Land and Soil Monitoring: a Guide for SoE and Regional Council Reporting. Land Monitoring Forum, Waikato Regional Council, Hamilton, New Zealand, pp. 117-178.

Lowe, D.J., 1986. Controls on the rates of weathering and clay mineral genesis in airfall tephras: a review and New Zealand case study, in: Colman S., Dethier D. (Eds.), Rates of chemical weathering of rock and minerals. Academic Press Orlando, USA, pp. 265-330.

Lowe, D.J., 1995. Teaching clays: from ashes to allophane, in: Churchman, G.J., Fitzpatrick, R.W., Eggleton, R.A. (Eds.), Clays: controlling the environment. Proceedings 10th International Clay Conference, Adelaide, Australia (1993). CSIRO Publishing, Melbourne, pp. 19-23.

Lowe, D. J., Palmer, D.J., 2005. Andisols of New Zealand and Australia. J. Integrat. Field Sci. 2, 39-65.

Lowe, D. J., Tonkin, P. J., 2010. Unravelling upbuilding pedogenesis in tephra and loess sequences in New Zealand using tephrochronology, in: Gilkes R. J., Prakongkep N. (Eds.), Proceedings of $19^{\text {th }}$ World Congress of Soil Science "Soil Solutions for a Changing 
World" (Brisbane), Symposium 1.3.2 Geochronological Techniques and Soil Formation, pp. 34-37. IUSS: published at http://www.iuss.org.

Lowe, D.J., Shane, P., Alloway, B., Newnham, R., 2008. Fingerprints and age models for widespread New Zealand tephra marker beds erupted since 30,000 years ago: a framework for NZ-INTIMATE. Quaternary Sci. Rev. 27, 95-126.

Lowe, D.J., Blaauw, M., Hogg, A., Newnham, R., 2013. Ages of 24 widespread tephras erupted since 30,000 years ago in New Zealand, with re-evaluation of the timing and palaeoclimatic implications of the Lateglacial cool episode recorded at Kaipo bog. Quaternary Sci. Rev. 74, 170-194.

Lowe, D.J., Balks, M.R., Laubscher, N., 2014. Once despised now desired: innovative land use and management of multilayered Pumice Soils in the Taupo and Galatea areas, central North Island, New Zealand. Guidebook for field trip "Hot volcanic soils”, New Zealand Society of Soil Science conference "Soil Science for Future Generations", Hamilton (1-4 December), $85 \mathrm{pp}$.

McDaniel, P., Lowe, D. J., Arnalds, O., Ping, C-L., 2012. Andisols, in Huang, P., Li, Y., Sumner M. (Eds.), Handbook of Soil Sciences, 2nd edition. Vol. 1: Properties and Processes. CRC Press, Boca Raton, FL, USA, pp. 33.29-33.48.

McGlone, M. S., Wilmshurst, J. M., Leach, H. M., 2005. An ecological and historical review of bracken (Pteridium esculentum) in New Zealand, and its cultural significance. New Zeal. J. Ecol. 29, 165-184.

McQuaker, N. R., Gurney, M., 1982. Sodium hydroxide fusion method for total fluoride, in Page A. L., Mill R. H., Keeney D. R. (Eds), Methods of Soil Analysis Part 2 Chemical and Microbiological Properties, $2^{\text {nd }}$ edition. American Society of Agronomy and Soil Science Society of America, Madison, USA, pp. 466-468. 
Mirlean, N., Roisenberg, A., 2007. Fluoride distribution in the environment along the gradient of a phosphate-fertilizer production emission (southern Brazil). Environ.Geochem. Hlth. 29(3), 179-187.

Nanzyo, M., 2002. Unique properties of volcanic ash soils. Global Environmental Research 6, 99-112.

Neall, V.E. 2006. Volcanic soils, in: Verheye, W. (Ed.), Land use and land cover, Encyclopaedia of life support systems (EOLSS). EOLSS Publishers with UNESCO, Oxford, U.K., pp. 1-24 (http://www.eolss.net).

Notario, J., Garcia, J., Caceres, J., Arteaga, I., Gonzalez, M., 1995. Characterization of natural phillipsite modified with orthophosphoric acid. Appl. Clay Sci. 10(3), 209-217.

Parfitt, R. L., 1978. Anion adsorption by soils and soil materials. Advances in Agronomy $30(1), 1-50$.

Parfitt, R., 1990. Allophane in New Zealand - a review. Aust. J. Soil Res. 28(3), 343-360.

Parfitt, R., 2009. Allophane and imogolite: role in soil biogeochemical processes. Clay Miner. 44(1), 135-155.

Parfitt, R.L., Pollok, J.A., Furkert, R.J. (Eds), 1981. Guide book for tour 1, North Island. Soils with variable charge conference, Palmerston North (February, 1981), 153pp.

Parfitt, R. L., Russell, M., Orbell, G. E., 1983. Weathering sequence of soils from volcanic ash involving allophane and halloysite, New Zealand. Geoderma 29, 41-57.

Parfitt, R., Saigusa, M., Cowie, J., 1984. Allophane and halloysite formation in a volcanic ash bed under different moisture conditions. Soil Sci. 138(5), 36-364.

Pawluk, S., Dudas, M., 1978. Reorganization of soil materials in the genesis of an acid luvisolic soil of the Peace River Region, Alberta. Can. J. Soil Sci. 58, 209-220.

Powers, M. C., 1953. A new roundness scale for sedimentary particles. J. Sediment. Petrol. $23,117-119$. 
Pullar, W.A., Birrell, K.S., 1973. Parent materials of Tirau silt loam. New Zealand Journal of Geology and Geophysics 16, 677-686.

Sigfusson, B., Gislason, S.R., Paton, G.I., 2008. Pedogenesis and weathering rates of a Histic Andosol in Iceland: Field and experimental soil solution study. Geoderma 144(3): 572592.

Singleton, P., McLeod, M., Percival, H., 1989. Allophane and halloysite content and soil solution silicon in soils from rhyolitic volcanic material, New Zealand. Aust. J. Soil Res. 27(1), 67-77.

Soil Survey Staff, 1999. Soil Taxonomy - a basic system of soil classification for making and interpreting soil surveys, 2nd edition. USDA-NRCS Agricultural Handbook 436. U.S. Government Printing Office, Washington, DC, 869 pp.

Soil Survey Staff, 2014. Keys to Soil Taxonomy, 12th edition. Washington, DC, USA: USDA-Natural Resources Conservation Service.

Sparks, D.L., 2012. Kinetics and mechanisms of soil chemical reactions, in Huang, P., Li, Y., Sumner M. (Eds.), Handbook of Soil Sciences, 2nd edition. Vol. 1: Properties and Processes. CRC Press, Boca Raton, FL, USA, pp. 13.1-13.30.

Staudigel, H., Chastain, R.A., Yayanos, A., Bourcier, W., 1995. Biologically mediated dissolution of glass. Chemical Geology 126 (2), 147-154.

Taylor, M. D., 2015. Soil quality monitoring in the Waikato Region 2012. Waikato Regional Council Technical Report 2015/02. Waikato Regional Council, Hamilton, New Zealand Available at http://www.waikatoregion.govt.nz/Services/Publications/Technical-Reports/ accessed 3/7/2015.

Taylor, M.D., Kim, N.D., 2009. Dealumination as a mechanism for increased acid recoverable aluminium in Waikato mineral soils. Soil Res. 47(8), 828-838. 
Taylor, M., Kim, N., Briggs, R., Taylor, A., Guinto, D., 2012. An investigation into the process of dealumination in soils of the Auckland, Bay of Plenty and Waikato regions of New Zealand. Appl. Clay Sci. 64, 18-24.

Thorseth, I. H., Furnes, H., Tumyr, O., 1995. Textural and chemical effects of bacterial activity on basaltic glass: an experimental approach. Chemical Geology 119 (1), 139-160.

Tuttle, M., Breit, G., 2009. Weathering of the New Albany Shale, Kentucky, USA: I. Weathering zones defined by mineralogy and major-element composition. Applied Geochem. 24(8), 1549-1564.

Tuttle, M.L.W., Breit, G.N., Goldhaber, M.B., 2009. Weathering of the New Albany Shale, Kentucky: II. Redistribution of minor and trace elements. Appl. Geochem. 24(8), 15651578.

Ugolini, F. C., Dahlgren, R. A., 1991. Weathering environments and occurrence of imogolite/allophane in selected Andisols and Spodosols. Soil Sci. Soc. Am. J. 55, 11661171

Ugolini, F.C., Sletten, R.S., 1991. The role of proton donors in pedogenesis as revealed by soil solution studies. Soil Science 151, 59-75.

Ugolini, F. C., Dahlgren, R. A., 2002. Soil development in volcanic ash. Global Environ. Res. 6, 69-81.

Ugolini, F.C., Dahlgren, R.A., Shoji, S., Ito, T., 1988. An example of andosolization and podzolization as revealed by soil solution studies, southern Hakkoda, northeastern Japan. Soil Science 145, 111-125.

Wolff-Boenisch, D., Gislason, S., Oelkers, E., 2004. The effect of fluoride on the dissolution rates of natural glasses at $\mathrm{pH} 4$ and $25^{\circ} \mathrm{C}$. Geochim. Cosmochim. Acta 68(22), 4571-4582. 
Yuan, G., Wada, S.-I., 2012. Allophane and imogolite nanoparticles in soil and their environmental applications, in Barnard, A.S. and Guo, H. (Eds.), Nature's Nanostructures. Pan Stanford, Singapore, pp. 494-515. 